Investigations

\title{
The Level of Milk Production, Depending on the Exterior Traits of Dairy Cows
}

\author{
Lyudmila Vasilevna Alimzhanova, Saule Kuanyshpekovna Bostanova, Yuliya Nikolayevna Sheiko, \\ Saltanat Aitymovna Issabekova and Baldyrgan Essentaevna Alimzhanova \\ Saken Seifullin Kazakh Agro Technical University, \\ Republic of Kazakhstan, 010011, Astana, Zhenis Avenue, 62, Kazakhstan
}

Article history

Received: 03-11-2017

Revised: 08-11-2017

Accepted: 27-12-2017

Corresponding Author:

Lyudmila Vasilevna

Alimzhanova

Saken Seifullin Kazakh Agro

Technical University, Republic

of Kazakhstan, 010011, Astana,

Zhenis Avenue, 62, Kazakhstan

E-mail: lyudmila-alimzhanova@yandex.ru

\section{Introduction}

Dairy cattle breeding is the leading branch of agriculture in the Republic of Kazakhstan. The annual production of milk on average is more than 4 million tons, which is clearly not enough to meet the needs of the population in milk and dairy products. In this connection, the task is to increase the volume of milk production by increasing the productive and breeding qualities of livestock.

One of the most important factors for accelerating selection work is the widespread introduction of world achievements in the field of genetics and breeding. The selection process in dairy cattle breeding depends on the method of estimating the pedigree value of cows, which will take into account not only such main productive features as milk, fat and protein content in milk, but also exteriors, udder health indicators, which is related to the duration of economic use of animals.

In the breeding of dairy cows, the assessment of the appearance of the animal plays an important role, since the exterior of the animal and its interior properties are closely related to dairy productivity.

A proper evaluation of the dairy cattle exterior makes it possible to determine the productive and breeding potential of both individual animals and the entire herd as a whole. Selecting animals on the exterior, the breeder indirectly selects them for productivity. The estimation of the exterior includes a general impression of the animal - typicality, severity of milk forms, the presence of defects and deficiencies (Ferguson, 2006; Kmutrovsky et al., 2010).

The linear evaluation of the type of physique is an image of the articles, based on the description of some of the most important exterior traits that have functional significance and are accountable. The linear method of assessing the exteriors makes it possible to obtain an objective idea of individual animals and herds as a whole, allows breeders to correct the selection in order to eliminate individual shortcomings of the cow's exterior and influence the type of the animal's body (Servakh and Rakhmatullina, 2008; Svyazhenta, 2007).

Correct application of the results of evaluation of the type of build in the selection of dairy cattle promotes an increase in the productivity of cows, easy flow of calving and an increase in the duration of their life (Zubryanov et al., 2001).

In recent years, the method of linear evaluation of the dairy cattle exterior in our country is used on different breeds - not only black-and-white cattle, but also other foreign and domestic animals. Carrying such an
Science

Publications 
assessment, we should not forget that each breed has its own standards and features related to the exterior and therefore the evaluation system should be adjusted (Oblivantsov, 2004; Prozherin et al., 2008).

\section{Materials and Methods}

The research was conducted in conditions of the Agrofirm "Rodina" and "Kamyshenka" of the Akmola region with a typical climate for Northern Kazakhstan.

The object of research was randomly selected cows Holstein black-and white and Simmental breeds in the number of 60 heads from each breed.

The aim of the research was to evaluate the dairy productivity and the exteriors of dairy Holstein blackand white cows and Simmental breeds linear method, as well as the relationship of individual features of the constitution and milk yield of these animals.

The research tasks included: to evaluate the dairy productivity and the exterior of Holstein black and breeds and Simmental by a linear method, as well as to elucidate the correlation between the individual features of the constitution and the yield of these animals.

Studied:

- Exterior traits of animals: a linear assessment, which includes 18 signs of the exterior Holstein black and white according to the Canadian technique and 19 signs of the exterior of the Simmental breed according to the Kazakh method, each of which is scored from 1 to 9

- Milk production (milking for lactation)

- Correlative relationship of individual features of the body and milk yield of these animals

The digital material is biometric processed by N.A. Plokhinsky using Microsoft Excel 2016.

Linear evaluation of the type of physique is a method of assessing the exterior traits of an animal using a quantitative scale. For each type of animal, its own rules for linear evaluation are adopted, separately for the black-and white Holstein breed and the Simmental breed, these techniques are presented below.

The Technique of a Linear Evaluation of the of Black-and-White Holstein Breed Exterior by the Canadian Technology

Type of Body: The type of the animal's body is assessed by the sharpness of the withers, the density (tenderness) of the skin and the backbone, the shape of the body, the thickness of the neck, the volume of the belly and the location of the ribs.

Strength Body: Strength of the body is estimated on the width of a breast which is defined by the distance between internal surfaces of the top part of upper legs limiting at the level of a brisket.

Height: The height of a cow is determined by the height in the sacrum, measured by the distance between the floor line and the highest point in the sacrum.

Body Depth: Body Depth is measured by the distance from the top of the spine to the bottom point of the belly along the line of the last rib.

Rump Angle: The rump angle is estimated by the position of the ischial tubercles to the marginal protrusions of the oyster piece bone when viewed from the side. The angle between the marginal protrusions of the conventionally drawn line from the oyster piece bones to the ischial tubercles. The rump angle is optimal when the ischial tubercles are 3-4 cm below the oyster piece bones.

Rump width: Rump Width is indicated by the distance between the caudal protrusions and ischial tubercles.

Hind Legs (Side View): The setting of the hind legs when viewed from the side is determined by the size of the angle formed by the bending of the hock. The optimal angle is 147 degrees.

Hind Legs (Rear View): The optimal value of the sign indicates the parallel arrangement of the limbs with respect to each other.

Hock Joint Status: The severity of the hock is determined by the dryness or thickening of the joint of the hind limbs.

Foot Angle: The angle of the hooves is determined by the angle of the upright hoof, i.e., the conventional angle between the line of the outer surface of the hoof and the floor and also the height of the calcaneal region of the hoof. The desired angle is 45-50 degrees; the height of the heel from the floor is more than $2-3 \mathrm{~cm}$.

Milky Forms: Milky forms are evaluated by the openness and the plane of the rib, the distance between the ribs and their slope, the leanness of the hips and the length of the neck.

Strength of Fore Udder Attachment: Strength of attachment of the fore part of the udder is determined by the angle between the fore parts of the udder and the abdominal wall.

Rear Udder Height Attachment: The attachment height of the rear part of the udder is estimated by the distance between the lower edge of the vulva and the upper edge of the glandular tissue.

Rear Udder Width: The width of the rear part of the udder is measured by the horizontal distance between the points of attachment of the udder to the body.

Udder Cleft: The udder cleft is estimated by the depth of the central ligament of parts, measured at the base of the udder from the rear, assessed by the severity of the udder cleft and the convexity of the udder base.

Position of the Bottom of the Udder: The position of the udder's bottom is estimated by the distance from the bottom of the udder to the hock. 
Fore Teat Position: The position of the fore teats is determined by their position relative to the center of the front quarters of the udder.

Rear Teat Position: The position of the rear teats is determined by their position relative to the center of the udder's hind quarters.

Teat Length: Teat Length indicates the length of the front teat; this means that the sizes of all teats should be the same. The optimal size is $5 \mathrm{~cm}$ (TIADCP, 2010).

\section{The Technique of a Linear Evaluation of the Simmental Breed Exterior by Kazakhstan Technology}

The following procedure has some differences from the Canadian limit values, as the cows of this breed differ in all the indicators studied.

Body Type: Body type is assessed as well as in blackand-white cows. An estimate of 1-3 points is obtained by animals having a rectangular trunk, a short massive neck, a rounded or bifurcate withers, a small angle of inclination of the ribs (closer to the straight), which are not visible, the bones are rounded; an estimate of 4-6 points characterizes the average indicators of these data. This feature is associated with dairy productivity.

Strength of Body: It is estimated also on width of a breast. The optimal value of the score is 8 points, this trait is associated with high productivity and animal health.

Height: The optimal value - 8 points, which corresponds to $142-144 \mathrm{~cm}$ tall is a good indicator of development in the growing period, high yielding during lactation, as well as body strength and health.

The Depth of the Body: Studies have established that the optimal value of the depth of the trunk should correspond to 7 points. The desirable expression of this feature is at a level of $80 \mathrm{~cm}$. The cows are estimated by their depth, which sufficiently characterizes the development of the digestive tract, the possibility of consuming a large amount of bulky fodder. An animal of a dairy type should have a deep, well developed, but not a loose stomach.

Stump Joint: It is characterized by the angle of inclination and the strength of the joints of the joint. The length of the joint is not taken into account when forming the evaluation.

The Length of the Sacrum: It is determined by the distance between the ischial tubercles and the marginal protuberance of the maclaka. This sign characterizes the ease of calving of the cow. The optimal value is 7 points.

Pelvic Angle: The optimal pelvic slope is considered when the ischial tubercles are 3-4 cm below the pups and it is estimated at 5 points. The sign characterizes the development of the organs and the ability of the cow to mild calving.

The Width of Rump: The optimum value of this attribute is 7 points. The wide back provides a large area for attaching the udder, broadens the birth canal, which contributes to easy calving.
Setting the hind legs (side view): With a saber-like setting of the hind limbs, the animal's body weight mostly falls on the tendons and ligaments, the weight of the body is mixed on the rear part of the hoof, which results in an excessive rapid erosion of the hoof walls. The symptom is related to the duration of economic use of the animal.

Setting the hind legs (rear view): Extremely close together in the hocks, the limbs can damage the udder while walking and promote the rapid wear of the joints. As the limbs come closer, the scores decrease, the optimal value is 7 points.

Expression of the Hock: On thick, cylindrical limbs and significantly thickened hock joints, 1 point is given and, as the sign is improved, their score increases, the optimal value is 9 points.

Hoof Angle: The angle of the hooves determines the ability to use cows in the herd for a long time. Strength of attachment of the udder's anterior lobes: A symptom is associated with the ability to prolong the use of cows in the herd and less likely to damage the udder. The best development of the stati is characterized by the gradual transition of the glandular tissue of the udder into the abdominal wall with the help of connecting ligaments.

Height of Attachment of the Udder's Lobes: The characteristic characterizes the capacity of the udder to fill with a large amount of milk, which promotes the appearance of a high milk yield.

The Width of the Udder's Lobes: A characteristic characterizes the creation of a large stock in the udder's volume. The optimal value is 6 points, in which the lateral edges of the udder are parallel to the extremities

Udder Beet: The optimal value is 9 points, the sign is related to the ease of milk yield, resistance to udder damage.

Position of the Bottom of the Udder: The optimal value is 5 points, which corresponds to the position of the bottom of the udder by $6-8 \mathrm{~cm}$ above the hock joint.

Arrangement of the front nipples and posterior nipples: The arrangement of the front nipples and the posterior ones, relative to the center of the udder quarters, characterizes its technological properties.

Teat Length: Nipple length is a very important technological feature that determines the ability of an animal to mild milk yield and resistance to mastitis (ARCBBRWTDCSB, 2014).

\section{Results}

The body build development is estimated between its limit values with a linear evaluation system. The evaluation of linear traits is independent of other elements of the evaluation. This means that other bodies do not influence the result of this point, but the results of a linear evaluation of this point influence the overall result of the evaluation. 
The cows of the first calving are evaluated during the period from the 30th to the 120th day of lactation and 2$3 \mathrm{~h}$ before regular milking.

The selective and genetic parameters of cows` conformation traits of Holstein black-and-white breed are shown in the Table 1.

According to this table, the cows' body strength of black and white breed will be weak as the optimal value for this trait of dairy cows is from 8 to 9 . The body depth will also be small and the optimal value is from 8 to 9 . The rump width will be narrow and the optimal value is also from 8 to 9 points. The pelvic angle is one of the well-developed trait, it is - $5.68 \pm 0.13$ points and milk molds are $5.97 \pm 0.16$ points, the optimal value is from 5 to 6 points for these indicators.

The selective and genetic parameters of the udder features of Holstein black-and-white breed cows are shown in the Table 2.

Based on the data obtained, the optimal indicators are such traits as the position of the udder's bottom, the udder furrow, the length of the treats, the front treats placement and the rear treats placement. The strength of the front udder attachments at a level of above average is $6.60 \pm 0.48$ points, which indicates animals' more rounded udder, which in turn is also a positive quality. The height of attachment of the udder lobes is also above the average of $7.02 \pm 0.50$ points, but the optimal value for this indicator is from 8 to 9 points. The width of the rear lobes of the udder is characterized by so-called milk mirror, however, this cow`s indicator has been at an average level of $6.52 \pm 0.34$ points, the optimal development for the indicator is also from 8 to 9 points.

Table 3 shows the selective and genetic parameters of the traits that reflect the cows` limbs position of Holstein black-and-white breed.

There were no deviations from the standard of development of these traits when analyzing the evaluation of the rear legs position. The optimal level of development for the low foot angle index is 5 points and these cow have only 0.05 less $-4.95 \pm 0.22$ points.

The correlation is one of the main terms in probability theory, showing the measure of the relationship between two or more random variables. This dependence is expressed in terms of the correlation coefficient.

Table 4 shows the correlation coefficients of the dairy cows` physiological characteristics.

As you can see from the table, the features of the physique are correlated positively. So the relationship of growth with the strength of the body and its depth is an average positive of +0.54 and 0.51 , respectively. The body strength with body depth have a high positive correlation +0.75 , which indicates a good development of the chest, containing vital organs. The milky molds with the same physical characteristics correlate negatively.
Table 5 shows the correlation coefficients between traits of Holstein black-and-white breed cows.

The average correlation was observed between the width of the rear udder lobes and height of their attachment +0.45 and this index also correlates positively with the length and attachment of the anterior lobes of the udder. The length of the front lobes of the udder is closely positively related to the measurements of the rear lobes, which indicates the harmonious development of the udder as a whole in highly productive dairy cattle. It should also be noted that with most of the measurements and features of the udder, the cow's milky molds are generally strongly positive (except for the width of the udder's back lobes, only +0.05). This indicates the successful indirect selection of animals for udder quality when selecting them for milky molds.

The high coefficients of correlation of cows on exterior features and milk yield indicates the expediency of conducting selection on these features first of all. Table 6 shows the correlation between the yield of blackand-white Holstein cows and some features of linear evaluation of these animals.

The average milk yield of black-and-white cows was $5927.8 \pm 0.52 \mathrm{~kg}$. Limits of milk productivity are 5141$11336 \mathrm{~kg}$.

According to the table there is always a positive connection except treats length. However, such indices as strength of build, depth of body, height, height of attachment of rear udder, udder cleft correlate with milk yield slightly, level is low $(+0.10-+0.23)$.. The relationship of the width of rear udder lobes and milk yield is average $(+0.51)$, which is to be expected, because the wider milk mirror is the higher the yield of the animals.

The results of the biometric processing of the linear estimation and the correlation between milk yield and the Simmental breed indexes are presented below.

Table 7 shows the selective and genetic parameters of the features of the Simmental breed cows.

It can be seen from the table that the average score for the build strength is approximated to the optimal value ( 8 points) $-7.35 \pm 0.12$, as the animals of this breed have larger physique and widely spaced front limbs. A lower score is awarded for cows of this breed $\ldots, 5.57 \pm 0.32$ points, limits are 3 to 8 points which is from $127 \mathrm{~cm}$ to $144 \mathrm{~cm}$, the coefficient of variability of this trait was $23.77 \%$. In general, according to the research, unlike Holstein, the animals of this breed differ slightly narrow, short and lowered posterior part of the body. Only a sign of the depth of the chest in these animals is close to the optimal value of 7 points, which is $6.67 \pm 0.15$.

The selective and genetic parameters of the udder measurements of the Simmental breed cows are shown in the Table 8 . 
Lyudmila Vasilevna Alimzhanova et al. / OnLine Journal of Biological Sciences 2018, 18 (1): 29.36 DOI: 10.3844/ojbsci.2018.29.36

Table 1: Selective genetic parameters of cows` conformation traits of Holstein black-and-white breed Selective-genetic parameters

\begin{tabular}{llll} 
Type traits & Average, $x$ & Standard deviation $(\sigma)$ & Coefficient of variability $(\mathrm{Cv})$, o \\
\hline Body strength & $7,82 \pm 0,20$ & 1,41 & 18,01 \\
Body depth & $7,50 \pm 0,12$ & 1,85 & 24,61 \\
Height & $7,23 \pm 0,14$ & 1,37 & 18,94 \\
Pelvic angle & $5,68 \pm 0,13$ & 1,31 & 23,02 \\
Rump width & $6,67 \pm 0,18$ & 1,63 & 24,49 \\
Milk molds & $5,97 \pm 0,16$ & 1,37 & 22,88 \\
\hline
\end{tabular}

Table 2: Selective-genetic parameters of udder features of Holstein black-and-white breed, point Selective-genetic parameters

\begin{tabular}{llll} 
Type traits & Average, $x$ & Standard deviation $(\sigma)$ & Coefficient of variability $(\mathrm{Cv}), \mathbf{0}$ \\
\hline Position of bottom of the udder & $5,48 \pm 0,50$ & 1,43 & 26,12 \\
Strength of fore udder attachment & $6,60 \pm 0,48$ & 1,2 & 18,12 \\
Height of rear udder attachment & $7,02 \pm 0,50$ & 1,62 & 27,46 \\
Width of rear udder & $6,52 \pm 0,34$ & 1,56 & 23,89 \\
Udder cleft & $6,13 \pm 0,65$ & 1,85 & 30,09 \\
Front teat position & $5,30 \pm 0,52$ & 1,29 & 24,39 \\
Teat length & $5,80 \pm 0,21$ & 1,30 & 22,40 \\
Rear teat position & $6,58 \pm 0,20$ & 1,78 & 27,01 \\
\hline
\end{tabular}

Table 3: Selective-genetic parameters of traits reflecting the cows` limbs position of Holstein black-and-white breed, point Selective-genetic parameters

\begin{tabular}{llll} 
Type traits, survey & Average, $x$ & Standard deviation $(\sigma)$ & Coefficient of variability $(\mathrm{Cv}), \%$ \\
\hline Rear legs position (side view) & $5,52 \pm 0,18$ & 1,61 & 29,19 \\
Foot angle & $4,95 \pm 0,22$ & 1,68 & 33,97 \\
Rear legs position (rear view) & $6,63 \pm 0,16$ & 1,68 & 25,28 \\
Hock joint status & $6,08 \pm 0,18$ & 1,67 & 27,46 \\
\hline
\end{tabular}

Table 4: Coefficients of correlation of traits of dairy cows` body of Holstein black- and -white breed

\begin{tabular}{|c|c|c|c|c|c|c|}
\hline \multirow{2}{*}{$\begin{array}{l}\text { Type traits } \\
\text { Strongly build (chest breadth) }\end{array}$} & \multicolumn{2}{|r|}{ Height } & \multicolumn{2}{|c|}{ Strongly build (chest breadt } & \multicolumn{2}{|c|}{ Depth of build } \\
\hline & & $+0,54$ & & & & \\
\hline Body depth & & $+0,51$ & $+0,70$ & & & \\
\hline Milky molds & & $+0,06$ & $-0,05$ & & $-0,22$ & \\
\hline Type traits & $\begin{array}{l}\text { Fore udder } \\
\text { attachment }\end{array}$ & $\begin{array}{l}\text { Length of } \\
\text { fore udder }\end{array}$ & $\begin{array}{l}\text { Height of rear } \\
\text { udder attachment }\end{array}$ & $\begin{array}{l}\text { Width of rear } \\
\text { udder lobe }\end{array}$ & $\begin{array}{l}\text { Distance of front } \\
\text { teat position }\end{array}$ & $\begin{array}{l}\text { Teat } \\
\text { length }\end{array}$ \\
\hline Length of fore udder & $+0,10$ & & & & & \\
\hline Height of rear udder attachment & $-0,07$ & $+0,07$ & & & & \\
\hline Width of rear udder & $+0,09$ & $+0,22$ & $+0,45$ & & & \\
\hline Distance of front teat position & $+0,13$ & $+0,02$ & $+0,27$ & $+0,17$ & & \\
\hline Teat length & $-0,29$ & $-0,02$ & $-0,09$ & $+0,06$ & $-0,04$ & \\
\hline Milky molds & $+0,33$ & $+0,33$ & $+0,24$ & $+0,05$ & $+0,30$ & $+0,18$ \\
\hline
\end{tabular}

Table 6: Correlation coefficients between milk yield and features of linear evaluation of black-and-white Holstein cows

\begin{tabular}{ll}
\hline Type traits & Correlation coefficient with milk yield \\
\hline Strength of build & $+0,12$ \\
Depth of build & $+0,26$ \\
Height & $+0,23$ \\
Width of rump & $+0,07$ \\
Milky molds & $+0,08$ \\
Height of rear udder attachment & $+0,10$ \\
Treat length & $-0,02$ \\
Udder cleft & $+0,20$ \\
Width of rear udder & $+0,51$ \\
\hline
\end{tabular}


Table 7: Selective -genetic parameters of features of cows` body of Simmental breed, point

\begin{tabular}{|c|c|c|c|}
\hline \multirow[b]{2}{*}{ Type traits } & \multicolumn{3}{|c|}{ Selective-genetic parameters } \\
\hline & Average, $x$ & Standard deviation $(\sigma)$ & Coefficient of variability $(\mathrm{Cv}), \%$ \\
\hline Strength of body & $7,35 \pm 0,12$ & 1,10 & 14,99 \\
\hline Depth of body & $6,67 \pm 0,15$ & 1,27 & 19,07 \\
\hline Height & $5,57 \pm 0,32$ & 1,32 & 23,77 \\
\hline Pelvic angle & $6,33 \pm 0,13$ & 1,02 & 16,10 \\
\hline Width of rump & $6,00 \pm 0,13$ & 0,99 & 16,52 \\
\hline Length of the sacrum & $5,68 \pm 0,18$ & 1,07 & 18,75 \\
\hline
\end{tabular}

Table 8: Selective-genetic parameters of traits of Simmental cows` udder, point

\begin{tabular}{llll}
\hline & Selective-genetic parameters & \\
Type traits & Average, $x$ & Standard deviation $(\sigma)$ & Coefficient of variability $(\mathrm{Cv}), \%$ \\
\hline Position of the bottom of the udder & $6,23 \pm 0,23$ & 0,98 & 15,73 \\
Strength of fore udder attachment & $5,55 \pm 0,38$ & 1,29 & 23,32 \\
Height of rear udder attachment & $4,62 \pm 0,48$ & 1,01 & 21,88 \\
Width of rear udder lobe & $5,22 \pm 0,31$ & 1,32 & 25,23 \\
Udder cleft & $5,10 \pm 0,63$ & 1,04 & 20,33 \\
Front teats position & $4,72 \pm 0,25$ & 0,90 & 19,16 \\
Treat Length & $5,78 \pm 0,32$ & 1,22 & 21,14 \\
Position of rear teats & $5,13 \pm 0,26$ & 1,13 & 21,95 \\
\hline
\end{tabular}

Analyzing the data obtained with a linear evaluation of the udder, it can be said that only the length of the treats was within the optimal value of $5.78 \pm 0.32$ points. All other indicators were below the optimal value. An important feature from the technological point of view is the distance from the bottom of the udder to the ground. The number of infectious diseases increases and there are no conveniences in milking machine with a low udder. The optimal value of this indicator is 5 points - at $6-8 \mathrm{~cm}$ above the hock, this indicator was $6.23 \pm 0.23$ points in our studies, which would be $11 \mathrm{~cm}$ above the hock. One of the lowest indices is the attachment strength of anterior part of the udder, which was $5.55 \pm 0.38$ and the udder cleft was $5.10 \pm 0.63$ points. Both indicators have an optimal value of 9 points. They also have the greatest coefficient of variation, more than $20 \%$. The animals of this group have the rounded shape of the udder, small udder and teats of these animals are similar.

Table 9 shows the selection and genetic parameters of the features that reflect the position of low extremities in Simmental breed cows.

The limb traits have the highest coefficient of variation up to $33.15 \%$ as shown in the table, which indicates the difference of this feature of cows in the group. As for the average points, all traits except the hock joint status were within the optimal value. The optimal value of this feature is 9 points. In our studies, Simmental was given a low score, because of the thickening and conical shape of the hock joint, their score was at the level of $5.12 \pm 0.38$.
It is important to establish the degree and direction of the relationship with other indicators in the selective breeding. If there is a positive correlation between the studied indicators, then we can say that the selection of animals for one indicator automatically leads to an improvement in another indicator.

Table 10 shows the correlation coefficients between the physiological characteristics of Simmental cows

The correlation coefficients between the physiological characteristics of the Simmental breed showed a positive relationship. So the height and depth of the body, the strength of build and the depth of build, the depth of the body and the width of the pose are characterized by an average positive connection. The correlation between the growth and strength of the physique, growth and width of rump is high positive. The low correlation was found between the width of the chest and the depth of the body +0.31 .

The correlation coefficients between the udder characteristics of Simmental cows are shown in the Table 11.

As can be seen from the table the indications of the cow` udder of this group are interrelated slightly. Only the average relationship is marked between the front treats and the height of attachment of the posterior lobes $(+0.37)$.

Table 12 shows the correlation between the yield of the Simmental breed and some features of the linear evaluation of these animals.

The productivity of Simmental cows was $4844.1 \pm 0.32$ $\mathrm{kg}$. The limit of milk production was $2559-5899 \mathrm{~kg}$. 
Table 9: Selective-genetic parameters of the traits reflecting the position of low extremities in cows of Simmental breed, point Selective-genetic parameters

\begin{tabular}{llll} 
Type traits & Average, $x$ & Standard deviation $(\sigma)$ & Coefficient of variability $(\mathrm{Cv}), \%$ \\
\hline Rear legs position (side view) & $4,80 \pm 0,42$ & 1,42 & 29,66 \\
Low Foot angle & $5,98 \pm 0,39$ & 1,49 & 24,90 \\
Rear legs position (rear view)7 & $4,97 \pm 0,46$ & 1,65 & 33,15 \\
Hock joint status 9 & $5,12 \pm 0,38$ & 1,38 & 26,95 \\
\hline
\end{tabular}

Table 10: Coefficients of correlation between signs of the Simmental breed`s physique

\begin{tabular}{llll}
\hline Type traits & Height & Strongly build (chest breadth) & Body depth \\
\hline Strongly build (chest breadth) & $+0,69$ & & \\
Body depth & $+0,45$ & $+0,31$ & $+0,48$ \\
Rump width & $+0,61$ & $+0,42$ & \\
\hline
\end{tabular}

Table 11: Coefficients of correlation between udder characteristics of Simmental cows

\begin{tabular}{llllll}
\hline Type traits & $\begin{array}{l}\text { Fore udder } \\
\text { attachment }\end{array}$ & $\begin{array}{l}\text { Length of } \\
\text { fore udder }\end{array}$ & $\begin{array}{l}\text { Height of rear } \\
\text { udder attachment }\end{array}$ & $\begin{array}{l}\text { Width of rear } \\
\text { udder attachment }\end{array}$ & $\begin{array}{l}\text { Distance between } \\
\text { front treats }\end{array}$ \\
\hline Length of fore udder & $+0,03$ & & & & \\
Height of rear udder attachment & $+0,02$ & $+0,07$ & & & \\
Width of rear udder attachment & $-0,04$ & $+0,11$ & $-0,12$ & $-0,16$ & $+0,09$ \\
Distance between front treats & $+0,12$ & $+0,12$ & $+0,37$ & $-0,05$ & \\
Treat length & $-0,04$ & $+0,15$ & $+0,02$ & & \\
\hline
\end{tabular}

Table 12: Correlation coefficients between milk yield and traits of Simmental cows `linear evaluation

\begin{tabular}{ll}
\hline Type traits & Correlation coefficient with milk yield \\
\hline Body strength & $+0,24$ \\
Body depth & $+0,26$ \\
Height & $+0,24$ \\
Width of rump & $+0,13$ \\
Height of rear udder attachment & $+0,08$ \\
Treat length & $-0,12$ \\
Udder cleft & $+0,06$ \\
Width of rear udder & $+0,23$ \\
\hline
\end{tabular}

In all cases, there is a positively low correlation between the traits and milk yields. With the exception of the length of the teats, where the correlation coefficient was negative. The height of attachment of the rear udder lobes and the udder furrow with milk yield correlate insignificantly, +0.08 and +0.06 , respectively

\section{Discussion}

The type of cow build, oriented to endurance and high productivity plays an important role in the effective production of dairy cattle. The study of the relationship between the traits of the exterior and the level of milk productivity will show whether the selection work is correct.

Our studies show a positive correlation between the indices of the udder and the yield of both breeds. The same results were obtained by the Turkish scientists Tapki and Guzey (2013) from Turkish Holstein cattle. The correlation coefficients between the pelvic angle, udder depth, the position of the posterior teat and milk productivity are 0.42 , $0.40,0.45$ respectively (Nemcova et al., 2011).
The relationship between the udder traits of the Holstein cows was at the mean level and the Simmentals traits were below positive. The scientists from Czech Republic (E. Němcová, M. Štípková, L. Zavadilová) received a high correlation coefficient between the indicators of udder bottom and udder depth - 0.75 , the correlation coefficients between the physiological traits were average positive (Nemcova et al., 2011). The same results were obtained by De Haas and others found a positive genetic correlation -0.22 , between the width of the hind parts of the udder and the width of the set point for Holstein (De Haas et al., 2007).

\section{Conclusion}

The correlation coefficients between physiological traits are positive in both groups.

According to the Holstein black and white cow's udder the milky forms are positively correlated with all the traits of udder, which indicates the harmonious development of the udder as a whole in highly productive dairy cattle.

In Simmentals, however, these relationships are weak. 
In both groups, there is a positive relationship between dairy indicators and signs of linear evaluation, but it should be noted that the Holstein breed has a correlation coefficient between the width of the hind portion of the udder and the milk yield and is +0.51 , while in the Simmentals, it is +0.23 .

Thus, the study of indicators of linear evaluation in dairy cattle and their interrelationship helps in improving the herd. An assessment of the variability of these traits makes it possible to assess the situation with the leveling of animals in the herd, as well as positive breeding work. Data on the correlation between individual traits and milk yields also facilitates the conduct of selection work, since by selecting animals according to one characteristic, we indirectly change the others associated with them.

\section{Acknowledgement}

We thank our University for reporting.

\section{Author's Contributions}

All authors contributed equally.

\section{Ethics}

Authors declare no conflicts of interest.

\section{References}

ARCBBRWTDCSB, 2014. Assessment regulations of cows` body builds of red-and -white type of dairy cattle of Simmental breed. Almaty.

De Haas, Y., L.L.G. Janss and H.N. Kadarmideen, 2007. Genetic and phenotypic parameters for conformation and yield traits in three Swiss dairy cattle breeds. J. Animal Breeding Genetics, 124: 12-19.
Ferguson, J.D., 2006. Body condition assessment using digital images. J. Dairy Sci., 89: 3833-3833.

Kmutrovsky, V., N. Ivanova and V. Puretsky, 2010. The Realization of the Genetic Potential of Black and White and Kholmogory Cattle when Creating Highly Productive Dairy Herds. 1st Edn., MosNIISH, Moscow, pp: 256.

Nemcova, E., M. Stipkova and L. Zavadilova, 2011. Genetic parameters for linear type traits in Czech Holstein cattle. Czech J. Animal Sci., 4: 157-162.

Oblivantsov, V., 2004. Linear estimation of the exterior of brown breed cows of Ukraine. J. Dairy Meat Cattle Breeding, 7: 35-38.

Prozherin, V.P., B.P. Zavertyaev and V.L. Yaluga, 2008. The linear assessment of the exteriors of cows of the Kholmogory breed. J. Zootechny, 12: 3-4.

Servakh, B. and N. Rakhmatullina, 2008. Exterior evaluation of dairy cattle. J. Livestock Russia, 5: 47-48.

Svyazhenta, M., 2007. Application of the linear technique in the assessment of the exterior of cows. J. Dairy Meat Cattle Breeding, 6: 23-25.

Tapki, I. and Y.Z. Guzey, 2013. Genetic and phenotypic correlations between linear type traits and milk production yields of Turkish Holstein dairy cows. Greener J. Agric. Sci., 3: 755-761.

TIADCP, 2010. The instruction on assessment of the dairy cattle physique. Astana.

Zubryanov, V.F., V.F. Lyashenko and I.M. Morozov, 2001. Exterior and productivity of black-and-white cattle of Volga type. J. Zootechnic, 4: 4-6. 